\title{
In vivo Evaluation of Marginal Microgaps of Sheep Incisors Filled with Two Composite Materials
}

\author{
Mária Figurová, Valent Ledecký, Svetoslav Štvrtina ${ }^{1}$ \\ Department of Small Animals, University of Veterinary Medicine, Košice, Slovak Republic \\ ${ }^{1}$ Medical Faculty of Komenský University in Bratislava, Slovak Republic
}

Received July 28, 2008

Accepted May 18, 2009

\begin{abstract}
The aim of the study was to evaluate the marginal microgaps of two light-induced polymerization composite materials: Filtek P60 (3M ESPE) and Opticor New (Spofa Dental) in ovine teeth in vivo.

The restorative materials were placed to type A-cavity to buccal surfaces of permanent teeth (Triadan system 301, 302, 303, 401, 402, 403). The variables of composite materials were evaluated in 3 groups of animals, 2 animals in each, at different time intervals (1, 6 and 9 months after beginning of the experiment). In various time intervals, 12 teeth per group were extracted under general injection anaesthesia, 6 teeth from each animal). Altogether 36 teeth were extracted throughout the experiment.

During the experiment we observed neither cracks nor marginal discoloration in both Filtek P60 and Opticor New restorations. Retention of all restorations was $100 \%$.

Significant $(P=0.029$ ANOVA) differences were observed in the dentin with Filtek P60 packable restorations which exhibited smaller marginal microgaps (OPTICOR NEW and dentin $11.09 \mathrm{~mm}$, FILTEK P60 and dentin $5.64 \mu \mathrm{m}$ ). The mean size of microgaps between dentin and the packable composite material Filtek P60 was significantly lower $(\mathrm{P}=0.029$ ANOVA) in comparison with the microhybrid Opticor New composite restorations. These materials are suitable as permanent restoration of dental cervical caries in sheep and other herbivores, such as those kept in zoological gardens and companion animals.
\end{abstract}

Light-cure filling, dentition, histology, restoration, sheep, experiment

At present, veterinary dentistry often deals with the issue of caries. Due to wrong feeding this disease is diagnosed especially in companion animals kept in apartments (Hale 1998; Capík 2007). Caries (caries dentinum) is a disease of hard dental tissues. It is a multifactorial disease (Vaško et al. 1994; Capík 2008). Advanced dental caries may result in indication for dental crown reconstruction using metal materials (Capík 2005). In stomatology practice, different types of restorations are used.

The size of marginal leakages between a filling and cavity wall represents an important evaluation criterion of filling materials in clinical stomatology. These microgaps arise mainly due to a polymerization shock as well as the coefficient of linear thermal expansion of the filling and hard dental tissues. In vitro study by Loguercio at al. (2004) evaluated these microleakages. Specimens were thermocycled (500 cycles between 5 to $55{ }^{\circ} \mathrm{C}$, analogous to changes of cold and hot feed and ingestion of liquids) and immersed in $0.5 \%$ methylene blue. The packable composites (e.g. Filtek P60) showed lower polymerization shrinkage compared to the hybrid resin. Food as a negative factor of polymerization shrinkage of composites is described by Attin et al. (1995) at the neck area of a tooth by post-operative sensitivity. When comparing the thermal expansion, Pucklett et al. (1995) concluded that classical glass-ionomeric cements have the lowest thermal expansion. The composites, on the other hand, exhibited the highest thermal expansion.

Microgaps arising between a composite filling and the cavity wall form an entry for percolation of both micro-organisms and liquids, possibly resulting in hypersensitivity,

Address for correspondence:

MVDr. Mária Figurová

Department of Small Animals

University of Veterinary Medicine

Komenského 73,041 81 Košice, Slovak Republic
Phone: +421904 584102

E-mail: figurova@konex.sk

composite@orangemail.sk

http://www.vfu.cz/acta-vet/actavet.htm 
pulp irritation, marginal discolorations and caries (Gojdišová 1997). At present, there is demand for composite fillings that would ensure a quality aesthetic filling (Attin et al. 1995).

In general, composite materials are hydrophobic and do not make a firm connection with a wet surface of both dentine and cement. This connection is possible to be made only with the help of primers and dentine adhesives. With enamel, a connection is made with the help of micro-retention achieved by enamel etching with phosphoric acid (35\% or $37 \%$ in accordance with dentistry manufacturer SpofaDental, 3M ESPE).

After restoration of enamel hypoplasia in canine teeth by a composite, Capík (1996) described better results in the neck and central part of a tooth than in the area of crown top where the fillings were detached frequently (occlusive pressure in dogs is $10 \times$ higher than that in humans). The defects in the first third of the crown were treated by removing unevenness and polishing the surface (Capík 1996).

\section{Materials and Methods}

The experiment was carried out between June 2002 and May 2003 at the Clinic of Surgery, Orthopaedics and Roentgenology, UVM Košice, accredited for experiments on animals conducted for scientific purposes (Act No. 115/95 of the Civil Code on Animal Protection), accreditation No. 12 766/02-220.

The study was carried out on 6 adult sheep with permanent teeth. Two composite materials were used to reconstruct class A cavities: Opticor New (microhybrid) and Filtek P60 (packable composite), both of lightinduced polymerisation exhibits. We evaluated the following variables: marginal microgaps, marginal colour stability, quality and retention of restorations of class A cavities in vivo. The experiment was conducted on animals with healthy dental tissues. The characteristics of composites were evaluated in 3 groups of animals, (2 animals per group) at various intervals (at 1, 6 and 9 months in sheep after the beginning of the experiment). At the above-mentioned intervals, we extracted and evaluated 12 incisors from sheep (a total 36 teeth during the experiment), under general anaesthesia. Histological and statistical data are on 36 teeth. We were not concerned with occlusive forces. Sheep were selected as experimental animals suitable for this purpose.

Preparation of class A cavity and their restoration was on animals under general anaesthesia.

Preparation procedure

Calculus was cleaned off the teeth and isolated from the buccal mucosa by means of paper cylinders. The prepared class A cavities were on the buccal surface of teeth. Those located on the left side of dentitions were restored with Filtek P60 (packable composite material) and those on the right side were restored with Opticor New (microhybrid composite material).

Opticor New: Box-shaped cavities were cut in buccal surfaces. The cavities were made with a diamond round bur and cone bur in a water-cooled high-speed handpiece.

After that, the enamel and dentin were etched with 37\% ortophosphoric acid (Etching gel) for $30 \mathrm{~s}$ for enamel and $15 \mathrm{~s}$ for dentin. Excess water was removed with air, avoiding dentin dehydration. Then we applied the adhesive system Retensin MT to the dentin and enamel surface for $10 \mathrm{~s}$. After that a thin layer ( $2 \mathrm{~mm})$ of microphil composite material Opticor New was applied to the cavity and was light-cured for 30-40 s, each layer (lightcured polymerization with $630 \mathrm{~mW} \cdot \mathrm{cm}^{-2}$ ).

Filtek P60

Box-shaped cavities were cut in buccal surfaces. The cavities were made with diamond round bur and cone bur in a water-cooled high-speed handpiece. After that the enamel and dentin were etched with 35\% phosphoric acid (Scotchbond-etchant) for $15 \mathrm{~s}$ for enamel and $15 \mathrm{~s}$ for dentin. Excess water was removed with air, avoiding dentin dehydration. We then applied adhesive system Adper Single Bond $2 \times$ to the dentin and enamel surface for 2-5 s. After that a thin layer $(2.5 \mathrm{~mm})$ of packable composite material Filtek P60 was applied to the cavity and was light-cured for $20 \mathrm{~s}$ each layer (light-cured polymerization with $630 \mathrm{~mW} \cdot \mathrm{cm}^{-2}$ ).

Checking on the status of fillings: 3 times per week

Premedication of all animals was achieved by administration of atropin a. u. v. at a dose of $0.05 \mathrm{mg} \cdot \mathrm{kg}^{-1}$ i.m. General anaesthesia in sheep was induced by i.m. administration of combination of xylazin a. u. v. and ketamin a. u. v. at a dose of $0.4 \mathrm{mg} \cdot \mathrm{kg}^{-1}$ and $5-10 \mathrm{mg} \cdot \mathrm{kg}^{-1}$.

The extracted teeth were conserved with $10 \%$ formalin. Specimens were prepared using water-hardened cynoacrylates. Sections were cut with a diamond saw and after hardening were embedded in solacryl. They were cut longitudinally and their thickness ranged between 100 and $150 \mu \mathrm{m}$. The width of microgaps was measured in $\mu \mathrm{m}$, separately for the dentin and enamel. Statistical evaluation of the size of microgaps was carried out by ANOVA and MANOVA. 


\section{Results}

Clinical evaluation of the sheep

All restorations in the 3 groups $(n=2$ each) were intact and showed no marginal discolouration.

In sheep of the $1^{\text {st }}$ ( 1 month following the restoration $), 2^{\text {nd }}$ ( 6 months following the restoration) and $3^{\text {rd }}$ group ( 9 months following the restoration), all the fillings were intact and without any marginal colour changes. The retention of restorations was $100 \%$ (Table $1)$.

No health complications occurred in the sheep throughout the study and their food intake and digestion corresponded to their physiology.

Table 1. Retention and colour stability of composite materials in sheep dentition

\begin{tabular}{|l|c|c|c|c|c|}
\hline \multirow{2}{*}{ Sheep } & Material & $\begin{array}{c}\text { Number of } \\
\text { evaluated } \\
\text { teeth }\end{array}$ & $\begin{array}{c}\text { Number of teeth } \\
\text { with separation } \\
\text { of restorations }\end{array}$ & $\begin{array}{c}\text { Retention of } \\
\text { restorations } \\
\%\end{array}$ & $\begin{array}{c}\text { Colour stability } \\
\%\end{array}$ \\
\hline \multirow{2}{*}{$1^{\text {st }}$ group (after 1 month) } & Opticor New & 6 & - & 100 & 100 \\
\cline { 2 - 6 } & Filtek P60 & 6 & - & 100 & 100 \\
\hline \multirow{2}{*}{$2^{\text {nd }}$ group (after 6 months) } & Opticor New & 6 & - & 100 & 100 \\
\cline { 2 - 6 } & Filtek P60 & 6 & - & 100 & 100 \\
\hline \multirow{2}{*}{$3^{\text {rd }}$ group (after 9 months) } & Opticor New & 6 & - & 100 & 100 \\
\cline { 2 - 6 } & Filtek P60 & 6 & - & 100 & 100 \\
\hline
\end{tabular}

Histology

Evaluating methods of MANOVA and ANOVA were employed in the study.

The intra-group factors were as follows: method / 2 levels: Opticor New and Filtek P60 / tooth ( 3 teeth were treated in each sheep using both methods).

The methods provided significantly different results $(P=0.033)$.

The results of MANOVA were used for ANOVA to detect which conversion (enamel / dentine) causes the overall significance of MANOVA (Tables 1-3).

The measurements in sheep showed that the mean span of leakages between dentine and composite OPTICOR NEW was $11.09 \mu \mathrm{m}$, and composite FILTEK P60 restorations was $5.64 \mu \mathrm{m}$ and the difference between the sizes was significant $(P=0.029$ ANOVA). The microgaps between sheep enamel and OPTICOR New was $3.08 \mu \mathrm{m}$ and FILTEK P60 was $1.69 \mu \mathrm{m}$ were non-significant ( $\mathrm{P}=0.338$ ANOVA) (Table 4), see Plate XIII, Figs 2, 3, Plate XIV, Figs 3, 4.

Table 2. MANOVA - intra-group effects

\begin{tabular}{|l|c|c|c|c|c|}
\hline Within subjects effect & Wilks' Lambda & F & Hypothesis df & Error df & P \\
\hline Method & 0.033 & 29.757 & 2.000 & 2.000 & $\mathbf{0 . 0 3 3}$ \\
\hline Method * Month & 0.015 & 7.212 & 4.000 & 4.000 & $\mathbf{0 . 0 4 1}$ \\
\hline Tooth & 0.713 & 0.461 & 4.000 & 10.000 & 0.763 \\
\hline Tooth * Month & 0.287 & 1.085 & 8.000 & 10.000 & 0.443 \\
\hline Method * Tooth & 0.204 & 3.028 & 4.000 & 10.000 & 0.071 \\
\hline Method* Tooth* Month & 0.365 & 0.819 & 8.000 & 10.000 & 0.604 \\
\hline
\end{tabular}

Method + Tooth + Method *Tooth

\section{Discussion}

When preparing the cavity it is very important to maintain the health of the pulp-dentine complex. This complex should exhibit a cellular activity demonstrated by high secretion activity of odontoblasts. To ensure subsequent secretory reaction of dentine at deep preparation it is 
Table 3. ANOVA - intra-group effects

\begin{tabular}{|l|l|c|c|c|c|c|}
\hline \multirow{2}{*}{ Source } & Measure & $\begin{array}{c}\text { Type III sum of } \\
\text { squares }\end{array}$ & Df & Mean square & F & \multicolumn{1}{|c|}{$P$} \\
\hline \multirow{2}{*}{ Method } & Enamel & 17.319 & 1 & 17.319 & 1.293 & 0.338 \\
\cline { 2 - 7 } & Dentin & 267.268 & 1 & 267.268 & 15.737 & $\mathbf{0 . 0 2 9}$ \\
\hline \multirow{2}{*}{ Method * Month } & Enamel & 22.456 & 2 & 11.228 & 0.838 & 0.514 \\
\cline { 2 - 7 } & Dentin & 376.928 & 2 & 188.464 & 11.097 & $\mathbf{0 . 0 4 1}$ \\
\hline \multirow{2}{*}{ Error (Method) } & Enamel & 40.188 & 3 & 13.396 & & \\
\cline { 2 - 7 } & Dentin & 50.950 & 3 & 16.983 & & \\
\hline \multirow{2}{*}{ Tooth * Month } & Enamel & 14.854 & 2 & 7.427 & 0.631 & 0.564 \\
\cline { 2 - 7 } & Dentin & 11.080 & 2 & 5.540 & 0.535 & 0.611 \\
\hline \multirow{2}{*}{ Error (tooth) } & Enamel & 35.762 & 4 & 8.940 & 0.759 & 0.588 \\
\cline { 2 - 7 } & Dentin & 91.694 & 4 & 22.923 & 2.212 & 0.184 \\
\hline \multirow{2}{*}{ Method * Tooth } & Enamel & 70.669 & 6 & 11.778 & & \\
\cline { 2 - 7 } & Dentin & 62.187 & 6 & 10.365 & & \\
\hline \multirow{2}{*}{ Method *tooth* Month } & Enamel & 7.642 & 2 & 3.821 & 0.734 & 0.519 \\
\cline { 2 - 7 } & Dentin & 48.232 & 2 & 24.116 & 8.086 & 0.020 \\
\cline { 2 - 7 } & Enamel & 12.147 & 4 & 3.037 & 0.583 & 0.687 \\
\hline \multirow{2}{*}{ Error (Method* Tooth) } & Enamel & 24.156 & 4 & 6.039 & 2.025 & 0.210 \\
\cline { 2 - 7 } & Dentin & 17.235 & 6 & 5.206 & & \\
\hline
\end{tabular}

The values indicate that the month of evaluation of microgap size is significant only with dentine $P=0.029$

Table 4. Estimated Marginal Means

\begin{tabular}{|l|l|c|c|c|c|}
\hline Measure & Composite materials & Mean & Standard error & \multicolumn{2}{|c|}{$95 \%$ Confidence interval } \\
\hline Enamel & Opticor New & 3.083 & 0.498 & 1.499 & 4.667 \\
\hline & Filtek P60 & 1.696 & 1.385 & -2.712 & 6.105 \\
\hline Dentin & Opticor New & 11.094 & 0.846 & 8.400 & 13.787 \\
\hline & Filtek P60 & 5.644 & 0.753 & 3.247 & 8.042 \\
\hline
\end{tabular}

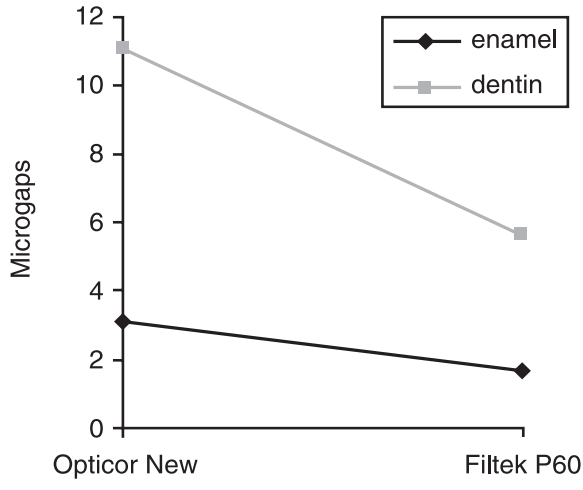

Method

Fig. 1. Evaluation of marginal leakages in $\mathrm{mm}$ at sheep dentin and enamel necessary to retain a sufficient layer of dentine - RDT - residual dentine thickness. A very thin and insufficient layer of RDT (thinner than $0.5 \mathrm{~mm}$ ) causes very low secretion reaction of dentine. This results in insufficient reparation (Murray et al. 2000).

Enrichment of composite material resins with the antibacterial compound Chlorhexidine (CHXA) has proven very efficient in slowing down the growth of a biofilm on the teeth surface compared to the commercial composite material Z 250 and glass-ionomer cements Fuji II LC and Fuji IX. In the course of several weeks, this bacterial mixture penetrated through the microgaps between the composite material Z 250 and dentine (Leung et al. 2005). Much lower volume of bacterial substance penetrated through composite materials enriched with CHXA (Leung et al. 2005). The sizes of microgaps observed in our study in pre-determined time intervals did not result in development of caries caused by penetration of liquids into the space between hard dental tissue and filling. 
Deliperi et al. (2002) investigated the problems related to microgaps arising at polymerization of composites on human teeth using a flow-material. This is a flowing micro-hybrid composite applied to dentine and enamel as a basis. By this method, mechanical properties of the fillings based on composites have been improved. Clinically, a lower occurrence of microgaps was confirmed. The number of broken fillings, repeated caries, and post-operative sensitivity decreased.

Kubo et al. (2004) used flow composite materials for filling neck cavities on buccal side of bovine incisors in vivo. The authors compared the variables of flow materials with those of a hybrid composite. The results of marginal integrity proved that separate use of flow materials resulted in a higher number and larger-size of microgaps compared to the use of hybrid composite.

Lin et al. (1997) observed decreased efficiency of composites in a 3-year study dealing with light polymerizing composites in aesthetic fillings of the $1^{\text {st }}$ class of premolars. Especially after the third year they detected failures in the form of secondary caries, detachment of material from the cavity and appearance of marginal stains.

In vivo study by Koliniotou-Koumpia et al. (2004) compared the range of microgaps in the cervical area of canine teeth using two techniques of adhesive system with composites. Much lower number of micro-slots has occurred when using total etching (dentine and enamel) compared to the self-etching system.

In the course of our study the durability of all fillings was $100 \%$. The employed technique of total etching has ensured $100 \%$ intactness of fillings throughout the study. The fillings were free of fractures and marginal stains.

In vitro studies by Abuabara et al. (2004) showed marginal leakages between composite material, glass-ionomer cement (GIC), and hard dental tissues (human, swine, and bovine teeth). Much larger marginal leakage was exhibited by samples with GIC than with a composite material. Samples from swine and bovine teeth showed significantly higher percentage of marginal leakages than those from human teeth. The samples exposed to the action of swine and bovine substrates showed higher marginal leakage than those in the human substrate.

Barros et al. (2003) compared the effect of different ways of polymerization of composite materials on development of microgaps. Better results were obtained at polymerization with a soft start and combined polymerization.

Loguercio et al. (2004) carried out an in vitro study to examine microgaps in cementenamel connection between different composite materials. Compared to hybrid composites, condensable composites had a lower number of micro-leakages in a cement margin at polymerization shrinkage. When comparing the size of microgaps between dentine, enamel and different filling materials (hybrid composite, condensable composite, flow composite, and ormocer), Yazici et al. (2004) found no significance.

In our study the measurements in sheep showed that the mean span of microgaps between dentine and composite OPTICOR NEW was $11.09 \mu \mathrm{m}$, and composite FILTEK P60 restorations was $5.64 \mu \mathrm{m}$ and the difference between the sizes were significant $(P=$ 0.029 ANOVA). The microgaps between sheep enamel and OPTICOR New was $3.08 \mu \mathrm{m}$ and FILTEK P60 was $1.69 \mu \mathrm{m}$ were non-significant $(P=0.338$ ANOVA).

Attar et al. (2004) investigated the significance of flow materials in terms of reduction of the number of microgaps at gingival margin combined with micro-hybrid and condensable composites. When using flow materials, the number of microgaps was reduced.

The results of in vitro studies conducted by Hasshoff et al. (2004) pointed to the importance of selection of suitable adhesive system primers. An ormocer was used in their study with a specific and universal adhesive system and a hybrid composite with a universal adhesive system. Statistically, the least measured micro-leakages were recorded with the combination of a specific adhesive system and ormocer. In our study, we used 
original, manufacturer-recommended adhesive systems and the technique of total etching (phosphoric acid 35\%, Scotchbond 3M ESPE) and etching with phosphoric acid 37\% (etching gel, SPOFA Dental). This approach resulted in minimum-size micro-leakages with enamel ( 0 to $3 \mu \mathrm{m})$.

The study of Santini et al. (2004), focused on evaluation of microgaps, showed no significant differences between the use of different types of self-etching agents and the technique of total etching with $36 \%$ phosphoric acid.

Fabianelli et al. (2003) compared marginal leakages between composite materials and hard dental tissues and observed a worse marginal leakage of composite materials in the cervical area compared to occlusion. The application of a thin layer of flow composite materials to the cervical area increased the marginal adaptation of condensable composite. The above authors observed lower occurrence of occlusive marginal leakages when using phosphoric acid. However, even the use of various flow composite materials in neck cavities failed to prevent fully the development of microgaps in a gingival margin of a filling. No flow materials were used in our study. The method of total etching we have used has ensured a minimum to zero size of microgaps between the enamel and the composite materials used.

The measured sizes of microgaps between composite FILTEK P60 and enamel and between OPTICOR New and enamel $(1.69 \mu \mathrm{m}$ and $3.08 \mu \mathrm{m}$, respectively) as well as sizes of microgaps between packable composite FILTEK P60 and dentine and between OPTICOR New and dentine $(5.64 \mu \mathrm{m}$ and $11.09 \mu \mathrm{m}$, respectively) had no effect on the development of caries in hard dental tissues.

Civelek et al. (2003) observed a higher number of microgaps in cement-enamel area when using combinations of composite material and a flow material compared to the use of composite material alone in cement-enamel region with all the variations of fillings as compared to occlusive margins.

\section{Hodnotenie okrajových netesností pri použití dvoch kompozitných materiálov na chrupe oviec $\mathrm{v}$ in vivo experimente}

Ciel'om experimentálneho štúdia bolo zhodnotit' ukazovatele okrajových netesností dvoch röntgenkontrastných kompozitných materiálov: Filtek P60 (3M ESPE) a Opticor New (Spofa Dental) in vivo na chrupe oviec.

Pri rekonštrukcii kavity typu A (bez porušenia cementosklovinného spojenia a bez porušenia pulpy) sme u oviec in vivo použili dva kompozitné materiály. Prvý z nich OPTICOR New, patrí medzi svetlom polymerizované mikrohybridné kompozity. Druhý kompozitný materiál FILTEK P60 je svetlom polymerizovaný kondenzovatelný univerzálny kompozit.

Ukazovatele kompozitných materiálov sme hodnotili v 3 skupinách zvierat po 2 ks $\mathrm{v}$ rôznych časových intervaloch (po 1., 6., 9. mesiaci od začiatku experimentu). Výplne boli umiestnené na bukálnej ploche trvalého zubu. V daných intervaloch sme v celkovej injekčnej anestézii extrahovali u oviec (v jednej skupine) 12 rezákov ( u každej ovce vždy po 6 zubov). Počas celého experimentu sa $v$ celkovej anestézii extrahovalo u oviec 36 zubov.

U oviec sme po 1., 6., a 9. mesiaci nezaznamenali ani jeden prípad uvol'nenia výplní. Stálost' obidvoch výplní bola 100\%-ná. Tieto výplňové materiály sa môžu použit' ako definitívne výplne do krčkových kavít u oviec (a iné prežúvavce a bylinožravce napr.v ZOO a domáci miláčikovia.

Všetky výplne z kompozitných materiálov Opticor New a Filtek P60 boli počas experimentu bez prasklín a bez okrajových farebných zmien.

Namerané vel'kosti okrajových netesností boli nasledujúce: Pri dentíne s kompozitom 
OPTICOR New bola priemerná vel'kost' netesnosti 11,09 $\mathrm{mm}$ a pri kompozite FILTEK P60 $5,64 \mathrm{~mm}$, pričom rozdiel poukazoval na významnost' $(P=0,029$ ANOVA). V práci sme použili hodnotiace metódy MANOVA, ANOVA.

\section{References}

Abuabara A, Santos AJ, Aguiar FH, Lovadino JR 2004: Evaluation of microleakage in human, bovine and swine enamels. Pesqui Odontol Bras 18: 312-316

Attar N, Turgut MD, Gungor HC 2004: The effect of flowable resin composites as gingival increments on the microleakage of posterior resin composites. Oper Dent 29: 162-167

Attin T, Buchalla W, Kielbassa AM, Helwig E 1995: Curing shrinkage and volumetric changes of resin-modified glass ionomer restorative materials. Dent Mater 11: 359-362

Barros GK, Aguiar FH, Santos AJ, Lovadino JR 2003: Effect of different intensity light curing modes on microleakage of two resin composite restorations. Oper Dent 28: 642-646

Capík I 1996: Hypoplázia skloviny u psov. Infovet 5: 38-39

Capík I 2005: Resistance of fractured canine teeth reconstructed by cast metal crowns with integrated post against pressure in vitro. In Proceedings: $14^{\text {th }}$ EVDS Congress, 22. - 25. 9., Ljubljana, pp. 49-51

Capík I 2007: Periodontal health vs. different preventive means in toy breeds - clinical study. In Proceedings: $16^{\text {th }}$ EVDS Congress, 14.-15. 9. 2007, Haag, 57-61

Capík I 2008: Endodontics in Small Animals, Proceedings: Miedzynarodowe Sympozjum Stomatologiczne, Lublin 24-25 May, Poland, pp. 55-58

Civelek A, Ersoy ML, Hotelier E, Soyman M, Say EC 2003: Polymerization shrinkage and mikroleakage in Class II cavities of various resin composites. Oper Dent 28: 635-641

Deliperi S, Bardwell DN 2002: An alternative method to reduce polymerization shrinkage in direct posterior composite restorations. J Am Dent Assoc oct 133: 1387-1398

Fabianelli A, Goracci C, Ferrari M 2003: Sealing ability of packable resin composites in class II restorations. J Adhes Dent 5: 217-223

Gojdišová E 1997: Estetická stomatológia I. Grada Publishing, pp. 9-138

Hale F 1998: Dental caries in the dog. J Vet Dent 15: 79-83

Hasshoff G, Schneider H, Merte K 2004: Tooth-composite interface from specific and nonspecific adhesive restorative systems. J Biomed Mater Res B Appl Biomater 71: 38-45

Koliniotou-Koumpia E, Dionysopolos P, Koump E 2004: In vivo evaluation of microleakage from composites with new dentine adhesives. J Oral Rehabil 31: 1014-1022

Kubo S, Yokota H, Yokota H, Hayashi Y 2004: Microleakage of cervical cavities restored with flowable composites. Am J Dent 17: 33-37

Leung D, Spratt DA, Pratten J, Gulabivala K, Mordan NJ, Young AM 2005: Chlorhexidine-releasing methacrylate dental composite materials. Biomaterials 26: 7145-7153

Lin H, Wang J, Yan W 1997: A three-year clinical evaluation of five light-cured composite resins in fillings of posterior teeth. Zhonghua Kou Qiang Yi Xue Za Zhi 32: 242-245

Loguercio AD, DE Oliveira Bauer JR, Reis A, Grande RH 2004: In vitro microleakage of packable composites in Class II restorations. Quintessence Int 35: 29-34

Malmstrom HS, Schlueter M, Roach T, Moss ME 2002: Effect of thickness of flowable resins on marginal leakage in class II composite restorations. Oper Dent 27: 373-380

Murray PE, About I, Lumley PJ, Smith G, Franquin JC, Smith AJ 2000: Post operative pulpal and repair responses. J Am Dent Assoc 131: 321-329

Puckett AD, Fitchie JG, Bennett B, Hembree JH 1995: Microleakage and thermal properties of hybrid ionomer restoratives. Quintessence Int 26: 577-581

Santini A, Ivanovic V, Ibbetson R, Milia E 2004: Influence of marginal bevels on microleakage around Class $\mathrm{V}$ cavities bonded with seven self-etching agents. Am J Dent 17: 257-261

Vaško J, Bachratý A, Javorka V, Mračna J, Satko I, Statelová D, Vodrážka J 1994: Stomatológia. Osveta, pp. 26-30

Yazici AR, Celik C, Ozgunaltay G 2004: Microleakage of different resin composite types. Quintessence Int 35: 790-794

Yazici AR, Ozgunaltay G, Dayangac B 2003: The effect of different types of flowable restorative resins on microleakage of Class V cavities. Oper Dent 28: 773-778 

Plate XIII

Figurová M. et al.: Evaluation of ... pp. 649-655

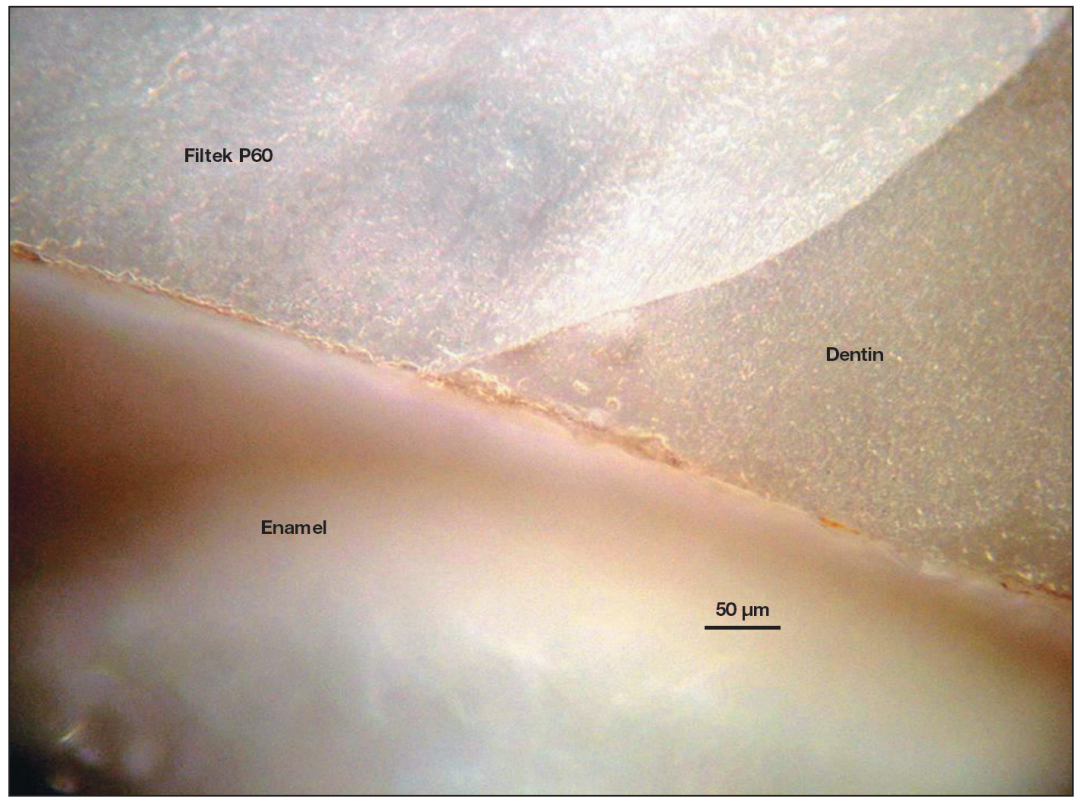

Fig.2. Sheep tooth with composite Filtek P60, native, magnification $\times 10$

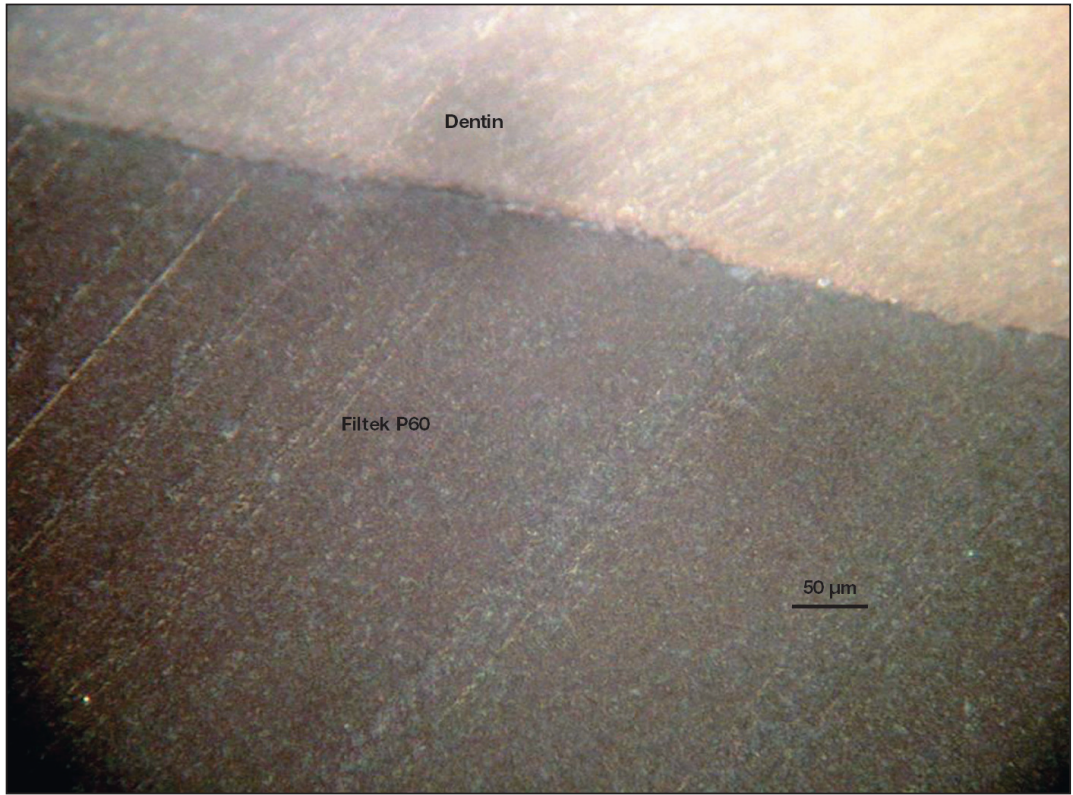

Fig.3. Sheep tooth with composite Filtek P60, native, magnification $\times 10$ 


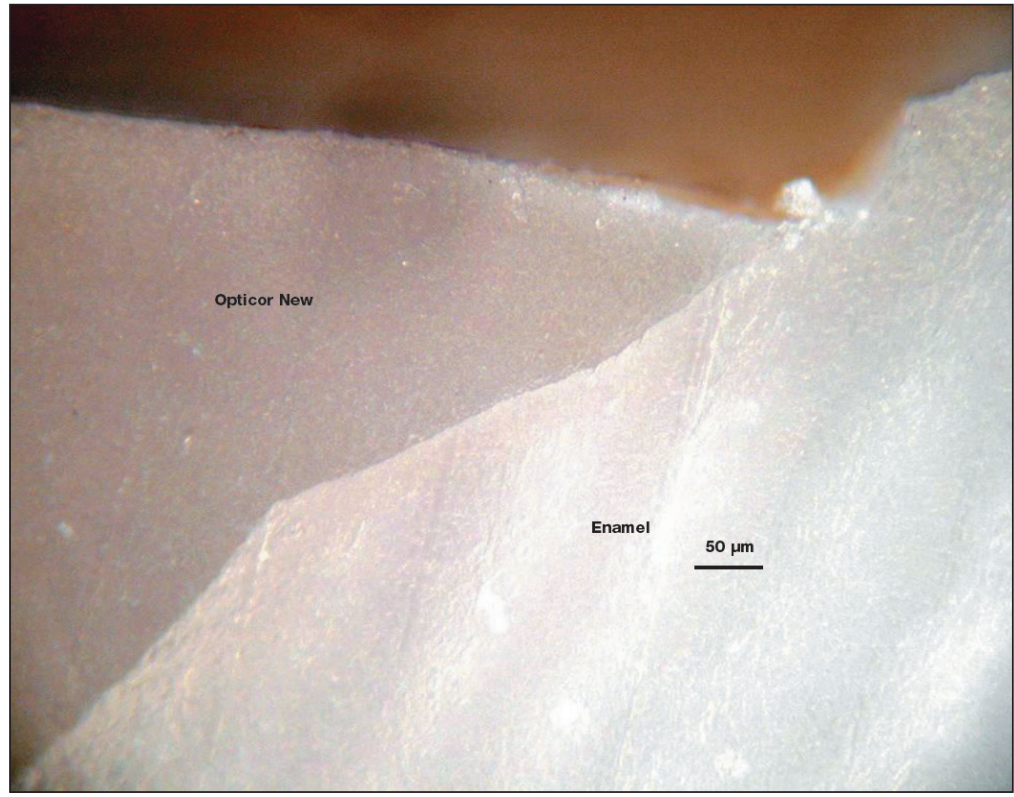

Fig.4. Sheep tooth with composite Opticor New, native, magnification $\times 10$

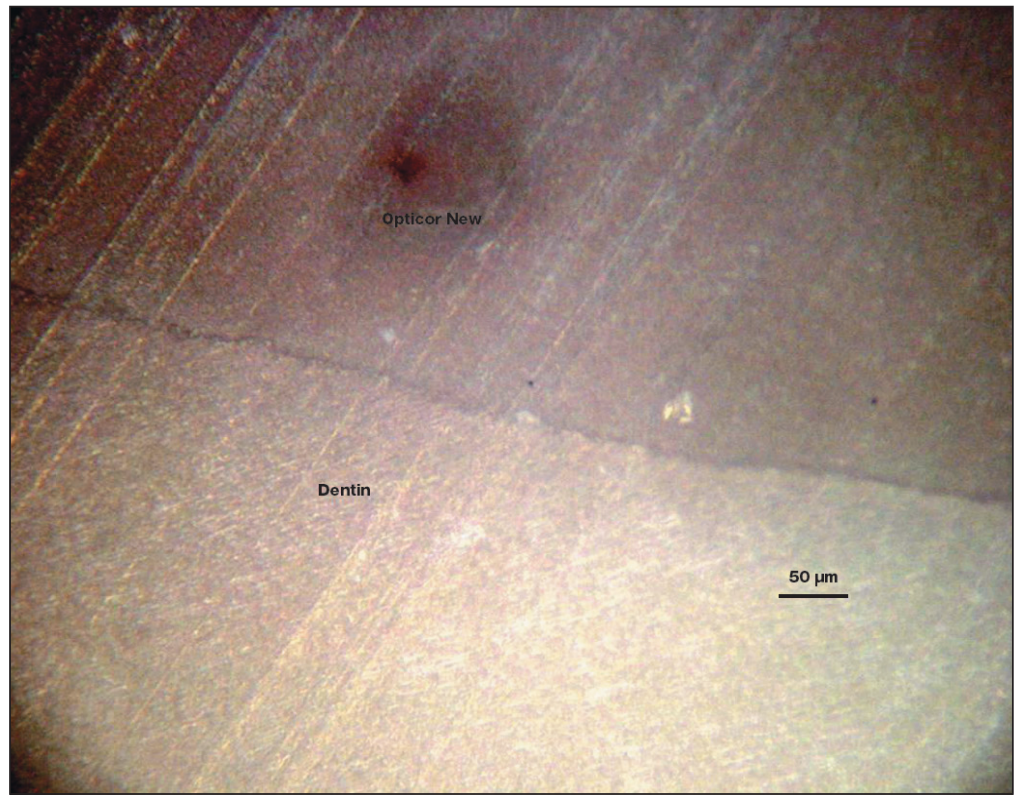

Fig.5. Sheep tooth with composite Opticor New, native, magnification $\times 10$ 